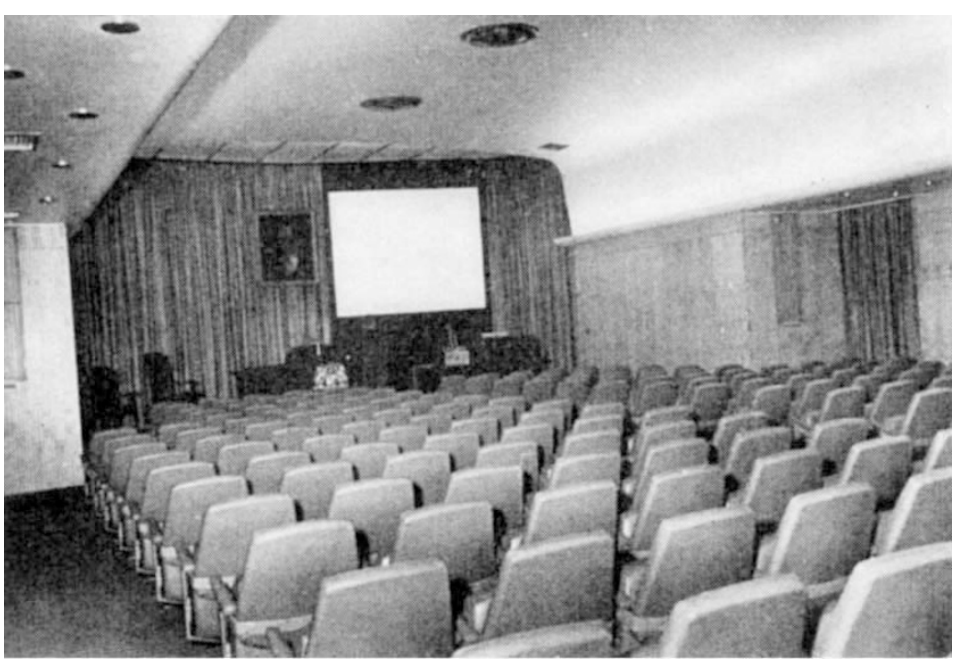

Large meeting hall and library at Cariton House Terrace.

\section{Moving House}

THe Royal Society has now completed its move to new premises at Carlton House Terrace, and the rooms were opened on Tuesday by the Queen, who is Patron of the Society. During the three centuries of its history the society has occupied six different sets of rooms, the most recent being at Burlington House, where it has been since 1857 . The new rooms, built between 1829 and 1832 to the designs of John Nash, are part of a fine terrace with an imposing array of Corinthian pillars stretching the full length. The terrace faces St James's Park and the Mall, and the society will be occupying the four houses at the eastward end of the terrace. ending at the Duke of York's steps.

The striking appearance of the houses from the outside has been preserved, but inside there has been a radical rebuilding, including, in the case of number 9 , the replacement of most of the load bearing walls below ground level. By removing walls, a lecture theatre capable of seating 250 people has been constructed in number 9 , and the society's library will take up all the deep basements and all the first floor at number 6 . All four houses have been knocked together to form one unit, modern heating and air conditioning have been installed and lifts and remodelled staircases have been built. Although the whole task could have been accomplished more cheaply by knocking down the old terrace and building anew, this would not have been permitted.

Much of the internal decoration, in a variety of styles, has been retained. The history of the houses is varied. Number 6 was once occupied by a Buenos Aires millionaire, $\mathrm{Mr} \mathrm{C}$. H. Sandford, who installed interior decoration of the most elaborate sort-mother of pearl ceilings, and Spanish and Florentine carvings and inlays - at the end of the nineteenth century. More recently, numbers 8 and 9 had housed the German Embassy in the era of Von Ribbentrop, and still bore traces of the taste of the Third Reich. Lord Holford, the architect for the conversion, barely conceals his feelings. In an article written for the society's own publicity, he describes the decoration: "Although it was not in a style (or mixture of styles) that would have been preferred by the Royal Society, or by any other learned society in the middle of the twentieth

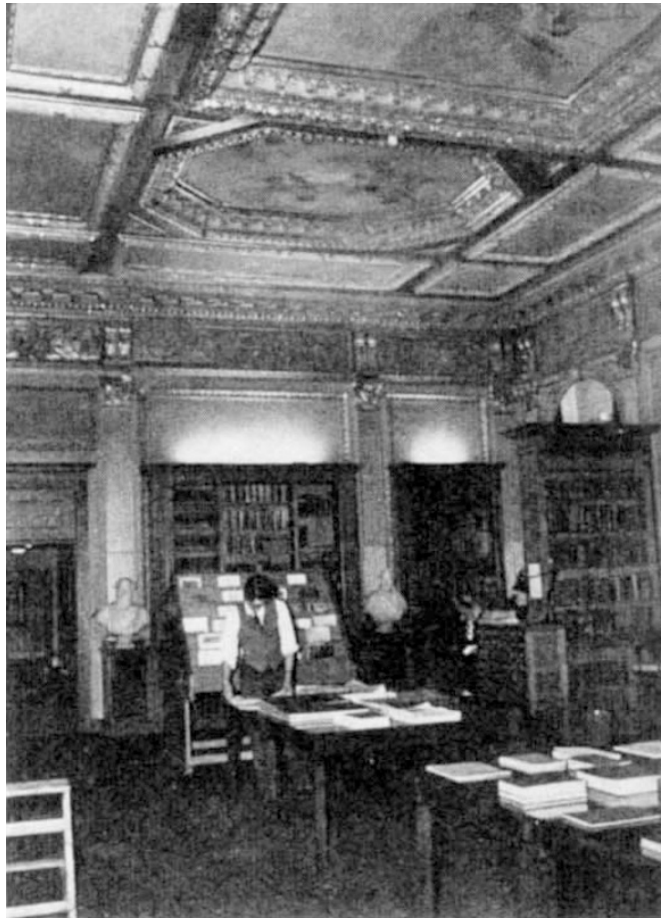

century, much of the existing decoration had to be retained". The basements, he says, were dungeon-like and the construction of the buildings indifferent. Only unusual advantages of situation and environment justified the conversion.

The society first showed an interest in moving to Carlton House Terrace in 1961. Originally it was thought that only Nos. 7, 8 and 9, with the basement of number 6, would be needed. In 1963, the Chancellor of the Exchequer gave his approval, announcing that the Government was prepared to pay the rent and annual maintenance for the 99 year lease of the four houses. The cost of conversion, then estimated at $£ 500,000$, was to be paid by the society. The floor space, 72,000 sq. ft., is more than two and a half times what was available at Burlington House. Furthermore, the President, Executive Secretary, and caretaker will all have flats in the new premises. (The present President, Professor P. M. S. Blackett, whose home is in London, will not be moving into his.) But the costs of the move were soon seen to have been underestimated, and they rose to $£ l$ million. By making a variety of economies, the bill was reduced to $£ 662,411$, but further increases since then have increased it again, to some $£ 850,000$. Of this money the Nuffield Foundation gave $£ 250,000$, the Government $£ 125,000$ and the Wellcome Trust $£ 103,000$. Despite a number of smaller benefactions, the full amount has yet to be collected.

The Royal Society's move has brought comfort to others than its own fellows. The premises which it has vacated in Burlington House are now being divided between a number of societies. The Chemical Society of London has inherited the lion's share of the old apartments (and has launched an appeal to equip them properly). The Royal Astronomical Society, much cramped in recent years, has acquired some breathing space. Yet there remains among the societies a somewhat depressed nostalgia for the old dream of one building for all the learned societies in London. 